\title{
MEMORIAL DE AIRES: ENTRE DRAMAS E ACORDES, A INFLEXÃO PARA A LITERATURA
}

\section{JURACY ASSMANN SARAIVA}

Universidade FEEVALE

Novo Hamburgo, Rio Grande do Sul, Brasil

Resumo: Memorial de Aires funda-se sobre a ativação da memória de Aires e reproduz a memória de Machado de Assis, a qual se nutre de produções artísticas de predecessores e de contemporâneos, desafiando o leitor a acessar o repertório de sua própria biblioteca para refletir sobre a contribuição das referências intertextuais à significação da narrativa e à manifestação do posicionamento crítico do escritor. Para tanto, o artigo situa o escritor no contexto cultural da segunda metade do século XIX e correlaciona a produção do diário às suas experiências estéticas, concluindo que remissões intertextuais reproduzem a atividade crítica de Machado de Assis, que se mostra integrada à dimensão múltipla e ilimitada da literatura, conjugando a adesão à tradição literária à sua transformação.

Palavras-chave: Machado de Assis; Memorial de Aires; relações intertextuais; música; posicionamento estético.

\section{COUNSELOR AYRES' MEMORIAL: BETWEEN DRAMAS AND CHORDS, THE INFLECTION FOR LITERATURE}

\begin{abstract}
Memorial de Aires is founded on the activation of the narrator's memory and reproduces the memory of Machado de Assis, which feeds on artistic productions of predecessors and contemporaries, challenging the reader to access the repertoire of his own library to reflect on the contribution of the intertextual references to the meaning of the narrative and to the manifestation of the critical position of the writer. For that matter, the article places the writer in the cultural context of the second half of the nineteenth century and correlates the production of the diary with his aesthetic experiences, concluding that intertextual references reproduce the critical activity of Machado de Assis, which is integrated into the multiple and unlimited dimension of literature, combining adherence to the literary tradition and its transformation.
\end{abstract}

Keywords: Machado de Assis; Counselor Ayres' Memorial; intertextual relationships; music; aesthetic positioning. 
Minha opinião é que a lenda é melhor do que a história autêntica.

Machado de Assis, 15 de setembro de 1876,

Ilustração Brasileira

\section{Rastros da memória na criação ficcional}

M

emorial de Aires, último romance de Machado de Assis, veio a público em $1^{\circ}$ de junho de 1908 , coroando a vida literária de seu autor, que faleceria quatro meses depois. No processo de criação desse romance, assim como o fizera em produções publicadas anteriormente, o escritor conjuga, à fantasia, fragmentos do real e elos intertextuais, instituindo um espaço metaficcional por meio de comentários sobre o ato de escrita e de referências que vinculam a significação do texto a obras da tradição literária ou da cultura do século XIX.

Acionados pela memória e transpostos para a ficção, autores e obras, personagens e ideias remetem a um saber pretérito em que o escritor se apoia para reativar sua significação, em consonância com o novo discurso de que passam a fazer parte. ${ }^{1}$ Essas transposições introduzem, pois, no mundo que as acolhe, virtualidades semânticas e sugerem uma apreciação valorativa de Machado, ao mesmo tempo que expõem sua experiência como leitor atento e como aficionado pela arte dramática e musical. Sob essa perspectiva, Machado sugere que o processo criativo decorre de um exercício crítico que migra da realidade circundante para textos e desses para aquela, em uma troca contínua, movimento que exige que também o leitor evoque suas lembranças sobre o fazer artístico para integrá-las ao exercício de interpretação que o texto lhe propõe.

Se a força criadora da memória se expõe como o modus operandi do escritor Machado de Assis, o atributo da deusa Mnemosyne também deflagra a narrativa em Memorial de Aires, sendo o fundamento do ato de narrar. A afirmação que abre o diário - "Ora bem, faz hoje um ano que voltei definitivamente da Europa" (ASSIS, 1986b, p. 1097) - não assinala apenas o

${ }^{1}$ Tiphaine Samoyault refere que o conteúdo se modifica visto que "as ideias não pertencem a ninguém, elas circulam" (SAMOYAULT, 2008, p. 52). 
Machado de Assis em Linha — Universidade de São Paulo

http://machadodeassis.fflch.usp.br

registro do tempo presente (1888, 9 de janeiro), mas resgata, sob o efeito do pregão de um vendedor de vassouras, um fato passado que o narrador relembra para identificar sua condição de diplomata aposentado, que retornara definitivamente ao Brasil.

A lembrança, desencadeada pela cantilena, mobiliza o conselheiro José Marcondes Aires a proceder à primeira notação, e é por meio do registro da memória, "recordando sensações, revivendo quadros, viagens, pessoas" (ASSIS, 1986a, p. 966), que ele concebe um universo diegético que também o delineia. Entrelaçados, os registros do diário e seu enunciador configuram um ao outro, emergindo, pela ação do ato da escrita, uma subjetividade ambígua em que a imagem pública do homem de salão - que se conduz como analista e intérprete das pessoas de seu convívio - se desdobra no misantropo - que cultua a própria interioridade e se protege da convivência alheia.

A dualidade do enunciador, que se desvela mais quando fala de outros do que quando fala de si mesmo (PAES, 2008), encontra correspondência na matéria diegética. $\mathrm{O}$ diário registra episódios ocorridos entre janeiro de 1888 e setembro de 1889, que instituem uma intriga aparentemente pouco densa. Ela pode ser sintetizada pelos interesses ambíguos do Conselheiro Aires por Fidélia, uma jovem viúva que jurara manter-se fiel à memória do marido; pelos vínculos afetivos que ligam a jovem ao casal Aguiar; pelo retorno, de Portugal, de Tristão, afilhado do casal, que, ainda criança, abandonara o Brasil, sem estabelecer qualquer contato com os velhos que o haviam amado como a um filho; pela recusa de Fidélia em casar-se com um advogado chamado Osório; pelo romance entre Fidélia e Tristão e pela alegria de Carmo e Aguiar com a intimidade dos jovens, pois julgam que o casamento poderá reter o rapaz no Brasil; pela frustração do casal de velhos - uma vez que Fidélia acompanha o marido em seu retorno à Europa -, e pelo registro de sua rendição à solidão, circunstância da qual o autor do diário compartilha.

Entretanto, a aparente singeleza do nível diegético se desfaz quando o Memorial é visualizado em seu processo enunciativo. O diário apresenta histórias distintas e entrelaçadas - a do casal Aguiar, a de Tristão e Fidélia, e a do próprio Aires, que são transpostas por um enunciador que se conduz simultaneamente como protagonista e testemunha dos episódios e que, embora se julgue lúcido e perspicaz, deixa-se iludir por aparências. A esse artifício técnico somam-se o cruzamento de tempos ficcionais, visto que a narração de eventos recentes remete a acontecimentos distantes; a 
Machado de Assis em Linha — Universidade de São Paulo

http://machadodeassis.fflch.usp.br

duplicidade avaliativa, gerada por pontos de vista discrepantes sobre personagens e situações, pois Aires soma às suas impressões a de outras personagens; a natureza falsamente documental do diário, que, todavia, expõe os artifícios de sua concepção, evidenciando que a escrita mimetiza procedimentos do real, sem, contudo, deixar de expor seus liames com a própria literatura.

Com efeito, análogo a uma colcha de retalhos, cujas emendas não sobressaem à primeira vista, o diário de Aires mostra, a partir da análise das referências intertextuais, uma composição heterogênea em que fragmentos do cotidiano provocam associações e lembranças, as quais servem para explicar aquelas. Fluxo inerente à constituição do diário, a memória torna-se objeto da reflexão do narrador que instala uma metamemória sobre a urdidura de seu texto e sobre o campo da arte, constituindo um jogo de espelhos em que a superfície da linguagem - aparentemente plana e monovalente - mostra fissuras e a irrupção de um nível subjacente de sentidos.

A remissão a formas de expressão artística, das quais o Conselheiro se torna intérprete, estabelece, assim, um contraponto entre elas e o diário e exige uma leitura verticalizada, além de instituir, de modo explícito ou implícito, a autorreferencialidade discursiva do Memorial. Esse procedimento, por meio do qual Aires metaforiza o trabalho do autor, traduz a artificialidade do processo de produção e questões estético-culturais que o envolvem, salientando a ruptura dos limites do texto literário, cuja construção se alicerça nas lembranças que a arte tem de si mesma.

Memorial de Aires funda-se, portanto, sobre a ativação da memória: a de Aires, instituída ficcionalmente e que reproduz a memória do escritor Machado de Assis; a desse, que se nutre de produções artísticas de predecessores e de contemporâneos. Por sua vez, o leitor é desafiado a acessar o repertório de sua própria biblioteca e a empreender uma leitura vertical, para refletir sobre a contribuição das referências intertextuais à significação da narrativa e à manifestação do posicionamento crítico do escritor.

Ainda que sejam múltiplas e variadas as menções intertextuais presentes no Memorial, no presente artigo restabelecem-se os vínculos que integram essa produção à lenda bretã Tristão e Isolda, à ópera de Richard Wagner em que ele recompõe a lenda, a um verso de Shelley e a trechos de cantigas medievais. Esses vínculos são representativos da presença da arte como sistema, da orientação estética de Machado de Assis, que transforma 
Machado de Assis em Linha — Universidade de São Paulo

http://machadodeassis.fflch.usp.br

suas evocações em elementos do processo de produção artística, assim presentificando seu entorno, bem como da participação do leitor, cuja memória cultural alimenta a significação do texto. Para tanto, visualiza-se o contexto sociocultural do Rio de Janeiro, identificam-se correlações entre a lenda bretã e a peça operística de Wagner e dessas com outros textos, para salientar a contribuição das referências metaficcionais à significação da narrativa e à reflexão poética de Machado de Assis.

\section{Fontes da memória literária}

A biografia de Machado de Assis e aspectos do contexto sociocultural do Rio de Janeiro conciliam-se para instituir fontes que alimentaram a memória literária e musical do escritor. A produção como poeta e dramaturgo, conjugada à função de censor do Conservatório Dramático, que exerceu a partir de 1862, promoveram a ativa inserção de Machado de Assis na vida cultural do Rio de Janeiro. Entre 1850 e 1870, apresentações musicais e encenações da dramaturgia nacional ou estrangeira ganhavam os palcos do Ginásio Dramático, do Teatro São Pedro, do São Januário e do Lírico Fluminense (MASSA, 1971).

Em 1841, fora criado o Imperial Conservatório de Música e, em decorrência dele, foi instalada, em 1857, a Imperial Academia de Música e Ópera Nacional, dirigida pelo espanhol José Amat. A instituição contou com o apoio de Machado de Assis, que para ela traduziu os libretos $A$ ópera das janelas (1857), Pipelet (1859) e As bodas de Joaninha (1861) (FARIA, 2010). Embora tivesse conseguido se manter apenas de 1857 a 1863, a Imperial Academia contribuiu para incentivar a produção de peças e de libretos em português por autores brasileiros, além de ter oferecido as condições necessárias à formação de Carlos Gomes (KIEFER, 1997), em cujas produções a influência de Wagner já se fazia sentir. ${ }^{2}$

Paralelamente, a partir de 1850, prosperaram empreendimentos dedicados à impressão de árias de óperas, de canções e de peças de compositores locais, bem como à comercialização de pianos e de outros instrumentos, o que estimulou o crescimento desse mercado e a

\footnotetext{
2 "Apesar do sentimento nacionalista que tomava conta da Itália por volta da época da unificação, o entusiasmo pela música alemã ganhava terreno mesmo sob grandes protestos da crítica nos jornais. A atração pela construção do drama musical através do uso contínuo de motivos condutores (leitmotiven), à maneira de Wagner, crescia e Carlos Gomes não ficou imune a isso" (CROWL, on-line, p. 6).
} 
Machado de Assis em Linha — Universidade de São Paulo

http://machadodeassis.fflch.usp.br

disseminação de costumes que valorizavam, mesmo no âmbito doméstico, a apreciação da arte musical (SAMPAIO, 2010).

Nas décadas de 1850 e 1860, o Rio de Janeiro recebeu importantes companhias operísticas e teatrais, sendo apresentadas óperas como Norma, de Vincenzo Bellini, Macbeth, O trovador e Ernani, de Giuseppe Verdi, Elixir de amor, de Domenico Donizetti, Otelo, de Gioacchino Rossini, destacandose a participação das cantoras líricas Anneta Casaloni Barbaglio, Anne Charton-Demeur e Augusta Candiani. Já os anos de 1869 e 1871 foram assinalados, respectivamente, pela vinda de Adelaide Ristori e de Ernesto Rossi e Tommaso Salvini, cujas carreiras estavam associadas às obras de Shakespeare. Os atores Ernesto Rossi e Tommaso Salvini proporcionaram ao público carioca o primeiro contato com a dramaturgia de Shakespeare, que, até aquela ocasião, havia sido encenada na forma de traduções de adaptações francesas (FARIA, 1993).

A cultura da música, após esse período, também foi dinamizada pela constituição de sociedades ou clubes que visavam difundir a arte clássica e pela visita de artistas de renome internacional. O Cassino Fluminense (1845), a Sociedade Filarmônica Fluminense (1860-1880), o Clube Mozart (1887), a Sociedade de Concertos Clássicos (1883), o Clube Beethoven (1882) - em que Machado desempenhou a função de bibliotecário - ofereciam concertos em que aberturas de óperas ou sinfonias eram apresentadas com frequência. Igualmente acolhiam, assim como os teatros, compositores e intérpretes internacionais, contribuindo para o desenvolvimento da arte dramática e musical.

Em decorrência da mobilização da sociedade carioca em torno da música, em 1887, Carlos de Mesquita ${ }^{3}$ inaugurou um ciclo de concertos sinfônicos populares, com o intuito de divulgar a música clássica para o grande público. Os espetáculos incluíam páginas de Richard Wagner, cuja produção e cujos ideais artísticos eram enaltecidos por Alberto Nepomuceno e por Leopoldo Miguez e aceitos pelos "nomes mais ilustres da época, nas letras e nas artes", instalando-se uma transformação "no gosto do público" (HEITOR, 1956, p. 98). Consequentemente, na década de 1880, "todas as grandes novidades das cenas europeias, óperas de Mascagni, Leoncavallo, Giordano, Puccini ou Massenet, eram logo apresentadas ao nosso público. E mesmo com o repertório de escol e de mais difícil montagem do drama lírico wagneriano ele se ia familiarizando" (HEITOR, 1956, p. 97).

\footnotetext{
${ }^{3}$ Carlos de Mesquita (Rio de Janeiro, 1864-Paris, 1953), professor de música, compositor e regente, foi pioneiro no desenvolvimento da música orquestral no Rio de Janeiro (CHUEKE, 2011, p. 241).
} 
Machado de Assis em Linha - Universidade de São Paulo

http://machadodeassis.fflch.usp.br

A evidência do compositor alemão e as polêmicas geradas em torno de sua produção ganharam espaço nas páginas dos jornais cariocas que, igualmente, registravam a admiração de d. Pedro II pelo autor de $O$ anel dos Nibelungos. Os números da Gazeta de Notícias de 24 de agosto e de 12 de setembro de 1876 noticiaram a visita que o imperador d. Pedro II fez a Wagner em Bayreuth, sendo informado, no segundo registro, "que S.M. o Imperador do Brasil, esteve nos dias 12, 13 e 14 em Bayreuth, na Alemanha, assistindo com o Imperador Guilherme, em casa de Ricardo Wagner, a representação de novas peças do célebre maestro" (GAZETA DE NOTÍCIAS, 1876, p. 1). Em página do mesmo periódico, Arthur Napoleão, amigo de Machado de Assis, comenta a presença do imperador no teatro wagneriano e exalta a grandiosidade do espetáculo, afirmando que músicos de todo o mundo "vieram render preito e homenagem ao regenerador da arte" (NAPOLEÃO, 1876, p. 1). Portanto, fosse pelas relações pessoais com Arthur Napoleão ou pela convivência com outros participantes do Clube Beethoven, fosse pela adesão às atividades da Imperial Academia de Música e Ópera Nacional ou, até mesmo, pelo fato de atuar na imprensa e de ser um contumaz leitor de jornais, Machado detinha informações sobre a produção de Wagner, o qual contava com um seleto número de admiradores entre os amantes da música clássica no Brasil.

Todavia, apesar do reconhecimento de seu espírito renovador, a música wagneriana disputava espaço com a popularidade de outros compositores alemães e franceses e, particularmente, com a ópera italiana, cuja hegemonia não desaparecera nas duas últimas décadas do século XIX, e, ainda, com um movimento de afirmação da brasilidade, sob o influxo do Romantismo tardio (BRANDÃO, 2012). Essa circunstância, apesar da notoriedade do compositor e da admiração que colhia entre músicos brasileiros, pode ter contribuído para a recepção pouco calorosa do público à primeira encenação de uma ópera wagneriana no país.

Na noite de 19 de setembro de 1883, estreava no Teatro D. Pedro II, pela Companhia Italiana do empresário Ferrari, o drama lírico em três atos Lohengrin, primeira ópera de Richard Wagner encenada no Rio de Janeiro (DIEGO, 2018, p. 222). A peça, porém, foi mal recebida "por um público que o lirismo místico do drama invencivelmente adormentava; percebia-se, durante os atos, a queda indiscreta dos binóculos e pequenas trousses femininas, escapulindo de mãos que o sono relaxava [...]" (HEITOR, 1956, p. 97). 
Machado de Assis em Linha — Universidade de São Paulo

http://machadodeassis.fflch.usp.br

Nove anos depois, em 30 de setembro de 1892, Tannhäuser é apresentada no Teatro Lírico, e a encenação foi recebida com entusiasmo, coadunando-se sua relevância com a força do movimento wagneriano que se constituíra no Brasil. O espetáculo merece de Machado de Assis um comentário cujo tom é simultaneamente sério e cômico e no qual a equiparação de Wagner a bondes elétricos e de Verdi aos bondes puxados por burros estabelece a oposição entre presente e passado e entre moderno e ultrapassado, interrogando-se o enunciador sobre a possibilidade da permanência do que se torna obsoleto devido à passagem do tempo e aos avanços da técnica:

Tannhäuser e bondes elétricos. Temos finalmente na Terra essas grandes novidades. O empresário do Teatro Lírico fez-nos o favor de dar a famosa ópera de Wagner, enquanto a Companhia de Botafogo tomou a peito transportar-nos mais depressa. Cairão de uma vez o burro e Verdi? (ASSIS, 1892)

Transcorridos quase dez anos da encenação Lohegrin, em 3 de setembro de 1893, Machado de Assis inicia seu comentário de A semana, na Gazeta de Notícias, pela menção a dois espetáculos teatrais, ambos já encenados:

Quando eu soube da primeira representação do Alfageme de Santarém, do pranteado e notabilíssimo escritor Visconde de Almeida Garret, como dizem respeitosamente os anúncios, e logo depois a do Lohengrin, de Wagner, fiz tenção de dizer aos moços que não desdenhassem do passado, e aos velhos que não recusassem o futuro. (ASSIS, 1893)

O comentário de Machado, no que se refere a Lohegrin, alinha-se ao que expressara sobre Tannhäuser e deixa claro seu posicionamento estético por meio do qual busca harmonizar duas tendências opostas: a do passado, representada por Almeida Garret, e a que projetava as inovações da expressão artística por meio de Richard Wagner. Em meio a reflexões sobre o cólera, cuja erradicação ainda não era uma certeza, e sobre o efeito de remédios, de que duvida, Machado conclui a crônica afirmando que "A verdade, como a beleza e de todos os tempos", possivelmente para contrapor a transitoriedade das circunstâncias e problemas humanos à permanência da arte, cujas mudanças não anulam sua essência, razão por que recomenda "aos moços que não desdenhem o passado e aos velhos que não recusem o futuro" 
Machado de Assis em Linha — Universidade de São Paulo

http://machadodeassis.fflch.usp.br

(ASSIS, 1893). Todavia, por meio da oposição entre o passado e o futuro, o cronista aponta para a divergência de opiniões do público apreciador da arte musical em relação à opera que estava sendo encenada.

Portanto, as apreciações de Machado de Assis sobre as óperas de Wagner revelam que ele não só tomou conhecimento das produções desse artista - cujo mérito exalta, sem com isso desmerecer criações daqueles que o precederam -, mas também assumiu um posicionamento em face das contestações que elas sofriam. Por conseguinte, a biografia intelectual de Machado de Assis atesta que ele participou ativamente da vida literária, teatral e musical do Rio de Janeiro, a partir do segundo semestre de 1856. Ele transferiu essa experiência para sua produção estética, seja pela recorrência à evocação de relatos colhidos no convívio com outros intelectuais, seja pela transposição de sua própria apreciação como leitor ou espectador. Assim, remissões intertextuais desvelam a memória do escritor que, por intermédio delas, agrega significações aos textos, expõe posições estéticas e revela aspectos socioculturais da segunda metade do século XIX. É essa memória literária e musical que explica o processo de especularização que se estabelece entre Memorial de Aires e Tristão e Isolda, tanto em sua versão verbal quanto operística.

\section{Tristão e Isolda: espelho entre espelhos}

A comovente história de amor de Tristão e Isolda tem por base uma lenda celta, cujo início provável se situa na primeira metade do século XII, embora não tenha sido concebida de uma única fonte. Desenvolvida progressivamente, ela se perpetuou durante séculos, graças à transmissão oral e ao registro de diferentes versões, as quais permitiram reconstituí-la no século XIX. Entre as versões, as mais citadas são as de Normand Béroul e a de Thomas da Inglaterra, a primeira redigida em 1170, e a segunda, em 1175. Essas versões foram reelaboradas pelos poetas Eilhart von Oberge e Gottfried von Straßburg, que registraram o romance em língua alemã. A do primeiro poeta foi publicada entre 1170 e 1190, e a do segundo, provavelmente, por volta de 1210. Apesar de ter permanecido incompleta, devido à morte de seu compilador, a versão de Gottfried von Straßburg foi primordial para o resgate da lenda por outros escritores, inspirando, igualmente, o compositor Richard Wagner na composição da ópera Tristão e Isolda, concebida entre 1857 e 1859 e encenada em Munique, no ano de 1865. 
Machado de Assis em Linha — Universidade de São Paulo

http://machadodeassis.fflch.usp.br

O Romance de Tristão também faz parte do Cancioneiro da Biblioteca Nacional, ${ }^{4}$ e ao personagem, que seria um bardo da corte do rei Artur, é atribuída a autoria de alguns lais da Bretanha, apresentados na abertura da obra. ${ }^{5}$ Além disso, em cantigas da lírica galaico-portuguesa, como na de $\mathrm{d}$. Dinis, há menções às personagens lendárias, visto que o trovador compara seu amor por uma donzela com o de Tristão por Isolda. Consequentemente, a lenda, popularizada pela tradição oral, difundiu-se também pelo registro escrito, vindo a fazer parte do substrato cultural do ocidente e ganhando novo vigor a partir do movimento de valorização das origens nacionais, desencadeado pelo Romantismo.

Nesse contexto, Machado convivia com escritores portugueses, como Francisco Gonçalves Braga e Augusto Emílio Zaluar, a quem atribuiu decisiva importância em sua iniciação no mundo das letras, e participava do Gabinete Português de Leitura, acolhendo informações que constituem a "enciclopédia" de seu saber literário, de que a lenda certamente fazia parte. Essa afirmativa também se sustenta pelo fato de o Memorial ser encimado por uma epígrafe, extraída da mesma coletânea em que se encontram as menções ao texto medieval e em que se reproduzem lais atribuídos a Tristão.

Reescrita, reinterpretada, enriquecida ou alterada por investimentos culturais, a lenda recebeu, entre 1900 e 1905, a versão de Joseph Bédier ${ }^{6}$ que a reconstituiu a partir de Béroul, de Thomas, de Eilhart von Oberge, de Gottfried von Straßburg e de fragmentos anônimos. Desde então, a obra de Bédier passou a ser referência para estudiosos da literatura ocidental, entretanto, é possível pressupor que excertos da lenda de Tristão e Isolda circulassem no Brasil antes do século XX, por meio dos Cancioneiros, ou que ela fosse veiculada por meio de relatos orais.

Também em um espaço de solidariedade intelectual insere-se a circulação da ópera Tristão e Isolda de Richard Wagner, a que Machado de

\footnotetext{
${ }^{4} \mathrm{O}$ nome de Cancioneiro da Biblioteca Nacional foi atribuído à compilação de cantigas trovadorescas reunidas por iniciativa do humanista Angelo Colocci (1467-1549), denominada Cancioneiro ColocciBrancuti. Adquirida pelo governo português em 1924, foi depositada na Biblioteca Nacional de Lisboa, razão de sua atual denominação (O CANCIONEIRO DA BIBLIOTECA NACIONAL, on-line).

5 "Os Lais de Bretanha, que introduzem a produção trovadoresca no Cancioneiro da Biblioteca Nacional, distinguem-se das demais composições daquela coletânea, por terem a sua autoria atribuída às personagens fictícias que, nos episódios correspondentes ao Romance de Tristão e da Suite du Merlin, os teriam composto" (VIEIRA, 2012, p. 667).

${ }^{6}$ O famoso medievalista Joseph Bédier (1864-1938) explica, no prefácio, a gênese de seu texto, que, embora seja constituído por excertos de outras narrativas, é resultado de um processo inventivo. A obra teve aproximadamente 600 edições sucessivas, foi traduzida em mais de 40 línguas e serviu de base para dezenas de adaptações em diferentes linguagens, sendo considerada uma obra-prima da literatura francesa do século XX (BÉDIER, on-line).
} 
Machado de Assis em Linha - Universidade de São Paulo

http://machadodeassis.fflch.usp.br

Assis não foi estranho, ou por ter tido acesso ao libreto ou a comentários, ou por ter apreciado sua execução musical nos círculos de que participava, como o Clube Beethoven, ou em ambientes domésticos. A partitura e o libreto de Wagner podem ter sido vendidos em lojas que comercializavam produtos musicais, e trechos da composição possivelmente foram executados em associações promotoras de música clássica ou até mesmo em saraus domésticos, ainda que a primeira apresentação dessa ópera do compositor alemão, no Rio de Janeiro, tenha ocorrido em maio de 1910, 45 anos depois de sua estreia na Europa.

As alusões de Machado de Assis à lenda de Tristão e Isolda justificamse, portanto, pelo contexto cultural, que permite presumir o conhecimento prévio dos leitores a respeito da narrativa bretã, e pela memória literária do escritor, que estabelece correlações, desdobra argumentos, agrega episódios, aproxima personagens, criando, no espaço ficcional, elos que integram textos entre si. Dessa forma, no Memorial, a narrativa do diário de Aires expande-se e, eliminando distâncias espaçotemporais, invoca a lenda celta e a ópera wagneriana, cujos pontos de conexão o leitor deve reativar por meio do diálogo intertextual.

Tanto o relato medieval quanto a ópera evoluem a partir de situações paralelas, as quais se caracterizam por traições, atos de bravura, rupturas entre os amantes e reconciliações, culminando com o encontro final, que é selado pela morte. Entre as diferenças no plano da diegese, pode-se destacar a intenção de Isolda de matar Tristão no primeiro ato, dando-lhe um bálsamo, visto que, na versão proveniente do substrato oral, ela desconhece a existência da bebida; o flagrante da traição que ocorre no jardim, sem que haja menção às inúmeras estratégias dos nobres, que desejavam denunciar os amantes ao rei. Finalmente, no texto operístico, Tristão é ferido pelo cortesão Melot, e não no campo de batalha, vindo a morrer depois de retirar o curativo do ferimento, embora Isolda tente curá-lo; no registro verbal da lenda, o cavalheiro já está sem vida quando ela o encontra.

No plano discursivo, a ópera, por sua natureza dramática, enfatiza a importância dos diálogos, aos quais cabe externar a intensidade da paixão dos amantes. Essa é acentuada pelo registro melódico e referendada pela participação dos atores que atuam como adjuvantes dos protagonistas. Em ambas as narrativas, sobressai o poder encantatório do amor, exacerbado pela poção mágica, cuja força anula os deveres ditados pelos laços de sangue, pelas normas da fidalguia, pelos preceitos legais, sendo os amantes perdoados em nome de um sentimento que é capaz de transcender a morte. 
Machado de Assis em Linha - Universidade de São Paulo

http://machadodeassis.fflch.usp.br

\section{Sob a circularidade da memória: acordes e dissonâncias}

Contraposta à lenda de Tristão e Isolda, a ópera wagneriana nela se espelha, como se lhe prestasse uma homenagem. Também Memorial de Aires se vincula à lenda e à ópera em atitude respeitosa, assinalando, porém, um distanciamento crítico em relação ao hipotexto, cuja presença serve para salientar o contraste entre a diegese, instituída pelo diário de Aires, e as das narrativas que celebram a perenidade do amor.

Com efeito, o nome Tristão, associado ao de Wagner - visto que a personagem executa "ao piano" (ASSIS, 1986b, p. 1134) uma peça musical do compositor -, é a ruptura que cinde o Memorial e dá ensejo ao estabelecimento de relações com as personagens lendárias. Ao permitir a analogia entre as narrativas, o nome Tristão instala a função de oponente a Aires, assim como o fora ao velho rei Marco, na disputa pelo amor de Isolda; da mesma forma, a sobreposição do nome do Conselheiro - Marcondes - ao do rei fundamenta a identificação entre ambos, por força da semelhança.

Todavia, a imagem projetada no espelho pelo Memorial mostra o esfacelamento ou a deformação da lenda, ainda que mantenha a identidade do núcleo temático: o conflito de um velho, cujas intenções amorosas são preteridas por incidir a escolha feminina sobre um jovem que, assim, como o da lenda, provém de além-mar. Insinua-se, ainda, na narrativa machadiana, o tema da traição, mas essa difere em relação à lenda, pois tem como vítima não o marido, mas os pais postiços de Fidélia e de Tristão e o Conselheiro, cujo desejo de despertar novamente o vigor da juventude o leva a imaginar um idílio amoroso com a jovem viúva.

Portanto, o diálogo entre Tristão e Isolda e Memorial de Aires instala-se a partir da identidade do fulcro temático, com a qual os nomes dos protagonistas e do compositor alemão se vinculam. Todavia, o conflito do velho Aires, cujas intenções amorosas ganham, no diário, a forma de uma encenação, sofre modificações. Elas provêm do deslocamento espaçotemporal, sobretudo, do emudecimento da voz épica, dos quais decorrem o afrouxamento da tensão das ações, a passividade de Aires, a contenção emocional e a alteração avaliativa do adultério.

Em Memorial de Aires, as aventuras heroicas da Idade Média dão lugar à monotonia do cotidiano de uma urbe não cosmopolita, a qual substitui a imensidão e a multiplicidade das florestas e dos palácios. A vastidão dos reinos restringe-se, em decorrência, ao reduto privativo dos salões, onde Aires circula como um exilado, exercendo a função de voyeur. A voz do 
Machado de Assis em Linha — Universidade de São Paulo

http://machadodeassis.fflch.usp.br

narrador épico - cuja veracidade não é contestada - é substituída pelo relativismo da enunciação de Aires, que precisa limitar-se ao que vê ou ao que ouve, devendo, ainda, obedecer à contenção das regras sociais que limitam a exposição das paixões e dos desejos.

Enquanto em Tristão e Isolda há a rendição a um amor incontrolável e o confronto explícito entre personagens, no texto memorialístico a ação se concentra na interioridade de Aires, que se divide, por um lado, entre a aceitação e a negação da própria senilidade e, por outro, entre a rendição ao apelo sexual ou às regras do convencionalismo social. Dessa forma, Aires assemelha-se ao rei Marco pela frustração amorosa, mas se opõe a ele pela impotência, visto que as circunstâncias que envolvem sua velhice não só o condicionam a mascarar os apelos da sexualidade, como também o impedem de declarar livremente seu desejo, estendendo-se a restrição em agir à censura no dizer (SARAIVA, 2009, p. 186).

Portanto, a relação entre as versões da lenda celta e a narrativa do conselheiro Aires assinala, na simetria, a diferença: a expansão ilimitada da sequência narrativa e as aventuras ou peripécias presentes no romance em verso e no texto operístico reduzem-se, no Memorial, a uma intriga pobre, embora lacunar. Entretanto, a rarefação de episódios assume uma condição icônica, uma vez que indicia as limitações do próprio narrador, que é prisioneiro de suas circunstâncias e da opacidade dos discursos daqueles com quem interage. Com efeito, ainda que assuma a função de decodificar e de registrar as motivações alheias, Aires ressente-se da falta de acesso à interioridade de Tristão, de Fidélia e de outras personagens, limitando-se a registrar conjecturas que substituem os acontecimentos.

A substituição do universo épico implica, também, uma mudança do posicionamento axiológico. Segundo a visão de mundo expressa na lenda medieval, a inevitabilidade da paixão adúltera redime os amantes, visto que eles não podem se subtrair aos imperativos do plano cósmico. No diário, Aires incrimina Fidélia e Tristão pela fraudulência de seus atos: ao casar-se, a viúva mostrara ser falsa a promessa de manter-se fiel ao primeiro marido; ela e Tristão enganam o casal Aguiar, fingindo que irão permanecer no Brasil; além disso, Aires sente-se traído, por não ter satisfeito o erotismo que Fidélia nele despertava.

Paralelamente, Aires pressupõe conduzir-se pela racionalidade e pela incredulidade - ao contrário da lenda, onde o universo mágico intervém -, devendo o diário registrar episódios verídicos e isentos de paixão. Entretanto, o conselheiro não apenas se rende à sedução das encenações 
Machado de Assis em Linha — Universidade de São Paulo

http://machadodeassis.fflch.usp.br

alheias como também às próprias, visto que, sob sua atitude ascética, deixa transparecer o erotismo, enquanto a negação de seus sentimentos esconde uma melancolia pungente. Consequentemente, se o fabuloso faz parte do passado lendário, nem por isso a ficcionalidade deixa de se introduzir no presente, contaminando a representação dos eventos do diário. Nele, também as emoções estão expressas, ainda que sejam negadas ou inspiradas na fantasia. Portanto, a lenda bretã, situada no mundo da ficção, nela se sustenta; já o diário, que tem por propósito analisar a realidade, assume a característica essencial do romanesco, negando o objetivo que afirma perseguir.

O diálogo do Memorial de Aires com as versões de Tristão e Isolda não esgota, porém, a convergência que o diário de Aires estabelece com o âmbito musical e operístico. Esse expande-se por meio do nome Fidélia, de um verso de Shelley e dos trechos das cantigas medievais que, na condição de epígrafes, compõem a abertura do texto.

Em 11 de fevereiro de 1888, Aires revela sua surpresa quanto ao nome de Fidélia e, apelando para a memória, anota:

Antigamente, quando eu era menino, ouvia dizer que às crianças só se punham nomes de santos ou santas. Mas Fidélia...? Não conheço santa com tal nome, ou sequer mulher pagã. Terá sido dado à filha do barão, como a forma feminina de Fidélio, em homenagem a Beethoven? Pode ser; mas eu não sei se ele teria dessas inspirações e reminiscências artísticas. (ASSIS, 1986b, p. 1113)

O registro de Aires, aparentemente aleatório, sublinha a intencionalidade de Machado de Assis, que evoca sua memória musical para articular o nome da protagonista ao tema da fidelidade amorosa, que está presente em Tristão e Isolda, e a que Ludwig van Beethoven dá forma na única ópera que compôs, denominada Fidélio ou o amor conjugal. Nessa, a protagonista Leonor, com o intuito de salvar o marido, o nobre Florestan, que fora injustamente encarcerado por Don Pizarro, um inimigo político, disfarça-se de homem, adotando o nome de Fidélio, o qual explicita o caráter leal e fiel da personagem. Leonor consegue localizar o marido na prisão e enfrenta seu inimigo com uma pistola, libertando Florestan, por quem demonstra um amor incondicional.

O nome Fidélia, em substituição ao de Isolda, reafirma o comprometimento amoroso, mas insinua, igualmente, a ideia de disfarce, aspecto que se ajusta à personagem da lenda celta e à do Memorial. Assim, 
Machado de Assis em Linha - Universidade de São Paulo

http://machadodeassis.fflch.usp.br

Aires constata, em Fidélia, uma atitude de simulada consternação quando a vê diante da sepultura do marido; levanta suspeitas sobre ela quando a encontra, por acaso, nas ruas da cidade, seguida, na primeira vez, por um olhar de admiração de Osório e, na segunda, de Tristão; sugere ter sido falsa a promessa de manter-se viúva, devido ao repentino relacionamento com Tristão. Consequentemente, inter-relacionam-se Fidélia e Isolda pelos artifícios da simulação, conjugando-se, mais uma vez, a arte musical e a literatura. Consequentemente, a remissão à ópera de Beethoven "permite compreender, por contraste, onde no romance se instaura a dúvida e como, no plano das ações, compromete-se a vigência da fidelidade" (MONTEIRO, 2008, p. 301).

Já o verso de Shelley - "I can give not what men call love" - repetido por Aires como uma espécie de refrão, reafirma a similaridade temática do Memorial com as versões de Tristão e Isolda. A consciência da senilidade gera a situação de conflito, experimentada por Aires, pois, enquanto a "graça apetitosa [da] mocidade de Fidélia" (ASSIS, 1986b, p. 1105) estimula o desejo, o verso de Shelley sugere sua incapacidade de amar. Portanto, a fantasia, instituída por devaneios, contrapõe-se à realidade da condição de sexagenário, esclarecendo não só o dilema do Conselheiro, mas também sua distinção em relação ao rei Marco: a impotência sexual.

Além de reforçar a aproximação do Memorial com o núcleo temático de Tristão e Isolda, o verso de Shelley vincula-se à intenção formal e semântica das epígrafes que abrem o diário, pois mimetiza a tautologia das cantigas medievais e extravasa um sentimento subjetivo, assumindo a funcionalidade de um refrão, que Aires obsessivamente repete. Todavia, impedido de viver uma paixão outonal, Aires comporta-se de modo ambíguo, conferindo diferentes conotações ao refrão, por meio do qual ora declara sua frustração amorosa, ora sublima a voluptuosidade de sua paixão por meio da exaltação estética, na medida em que relata o envolvimento amoroso dos filhos postiços do casal Aguiar.

A natureza paradoxal do comportamento de Aires também é explicada pelas epígrafes, cuja seleção deve ser atribuída ao editor do diário do Conselheiro. Ao apropriar-se do Memorial, o editor interpreta-o e expande-o por meio das epígrafes, que, como um comentário explicativo, assumem uma função autorreferencial: sob o ângulo semântico, elas antecipam o enredo visível e sugerem o sentimento amoroso de Fidélia e sua inevitável separação dos pais adotivos; sob o ângulo formal, as epígrafes apontam para regras que orientam a execução do Memorial, entre as quais a do velamento da 
Machado de Assis em Linha — Universidade de São Paulo

http://machadodeassis.fflch.usp.br

linguagem e do diálogo entre textos, além de presentificar o fingimento poético que caracteriza as cantigas medievais. Sob esse ângulo, Aires assume a função do trovador e dá voz ao sentimento feminino, mas, contraditoriamente, traduz, também, a manifestação elegíaca própria. Entretanto, as convenções - que aproximam a narrativa do diário e os fenômenos líricos medievais - conferem às epígrafes outra significação: por um lado, sintetizam a história, denunciando a falta de sinceridade dos sentimentos filiais de Fidélia e Tristão; por outro, expõem a artificialidade da narração do diário, sugerindo que o amor de Aires por Fidélia é um fingimento, cuja dilemática situação lhe proporciona a ilusão de vida.

Portanto, como intérprete do diário, o editor articula as epígrafes à solidão e carência de Aires, à experiência passional de Tristão e Fidélia que o Conselheiro relata, às menções do verso de Shelley e às sugestões suscitadas pelos nomes Wagner, Tristão, Fidélia e Beethoven. Na circularidade das menções intertextuais, emerge a memória do escritor Machado de Assis, que, ao integrar música e literatura, parece afirmar, em sintonia com o Conselheiro: "Como eu ainda gosto de música! [...] A música foi sempre uma das minhas inclinações, e, se não fosse temer o poético e acaso o patético, diria que é hoje uma das saudades" (ASSIS, 1986b, p. 1142).

Assim, se, na representação vicária da escrita do diário, o protagonista registra o "poder subversivo da memória" (PASSOS, 1996, p. 161), no processo de escrita, o escritor Machado de Assis aciona sua memória e a do leitor, interpelando-o a identificar, na ficção, "o distanciamento da reflexão constante" (PASSOS, 1996, p. 150). Consequentemente, no Memorial de Aires, por meio da remissão à lenda de Tristão e Isolda, tanto em sua versão verbal quanto operística, a um verso de Shelley, à ópera Fidélio, a trechos de cantigas medievais, Machado de Assis não só expande o campo das significações de sua narrativa, mas também externa sua admiração em relação às obras com as quais dialoga. Dessa forma, encimadas pelas epígrafes, as menções do Memorial atuam como simulacros, mediante os quais a ficção reflete sobre a ficção, indiciando, simultaneamente, as convicções estéticas do escritor e seu contexto cultural.

Leitor contumaz, crítico literário e teatral, apreciador de música, Machado de Assis transfere suas experiências para a produção ficcional, estabelecendo uma correlação entre a vida e a literatura, compreendidos como universos semânticos justapostos e permeáveis. Paralelamente, estende a ideia de convergência à própria concepção de arte: endossando a natureza sistêmica da arte, ele anula, no plano da recepção, a distinção entre 
Machado de Assis em Linha - Universidade de São Paulo

http://machadodeassis.fflch.usp.br

linguagens e a sucessão cronológica de obras, para sublinhar a importância de suas significações e de seus elos de simultaneidade. As remissões intertextuais reproduzem, portanto, a atividade crítica do escritor que se mostra integrado à dimensão múltipla e ilimitada da literatura e que conjuga a adesão à tradição literária à sua transformação.

Além disso, o exercício da intertextualidade, praticado por Machado, também instala uma compreensão renovada da sociedade carioca da segunda metade do século XIX. A partir das referências à arte literária e musical, a valorização da leitura e da literatura se destaca em um contexto em que poucos sabiam ler; a identificação de obras e de autores em circulação ganha contornos mais nítidos; espetáculos musicais, líricos e dramáticos ganham importância em uma sociedade que busca equiparar-se à burguesia europeia, e a frequentação do teatro manifesta-se como forma de lazer e de interação entre indivíduos. Esses aspectos expõem a memória de Machado de Assis, retiram do passado a sociedade em que ele viveu e contribuem para elucidar suas apreciações valorativas em relação à arte.

\section{Referências}

ASSIS, Machado de. 15 de setembro de 1876. Ilustração Brasileira, Rio de Janeiro, 15 set. 1876. Disponível em: <http://www.cronicas.uerj.br/home/cronicas/ machado/rio_de_janeiro/anol876/15set76.htm>. Acesso em: 16 nov. 2018.

. 02 de outubro de 1892. A Semana, Rio de Janeiro, 02 out. 1892. Disponível em: <http://www.machadodeassis.ufsc.br/obras/cronicas/CRONICA,\%20A\% 20semana,\%201892.htm\#C1893>. Acesso em: 16 nov. 2018.

. 03 de setembro de 1893. A Semana, Rio de Janeiro, 03 set. 1893. Disponível em: <http://www.machadodeassis.ufsc.br/obras/cronicas/CRONICA,\%20A\% 20semana,\%201892.htm\#C1893>. Acesso em: 16 nov. 2018.

. Esaú e Jacó. In: Obra completa. Rio de Janeiro: Aguilar, 1986a. v. 1. Memorial de Aires. In: . Obra completa. Rio de Janeiro: Aguilar, 1986b. V. 1.

BÉDIER, Joseph. Le Roman de Tristan et Iseut. Disponível em: $<$ http://www.droz.org/world/en/4785-9782600015486.html>. Acesso em: 16 nov. 2018.

BRANDÃO, José Maurício. Ópera no Brasil: um panorama histórico. Revista Música Hodie, Goiânia, v. 12, n. 2, 2012 Disponível em: <https://www.revistas.ufg.br/ musica/article/view/22543/13404>. Acesso em: 16 nov. 2018.

CHUEKE, Isaac. Francisco Braga, um compositor brasileiro e seu estilo. In: FÓRUM DE PESQUISA CIENTÍFICA EM ARTE, 7., 2011, Curitiba. Anais... 
Machado de Assis em Linha - Universidade de São Paulo

http://machadodeassis.fflch.usp.br

Curitiba: Embap, 2011. p. 240-246. Disponível em: <http:// www.embap.pr.gov.br/arquivos/File/Forum/anaisvii/240.pdf $>$. Acesso em: 18 nov. 2018.

CROWL, Harry. A música de Richard Wagner e a sua influência no Brasil. Disponível em: <http://blog.goethe.de/wagner/uploads/RichardWagnereo Brasil.pdf $>$. Acesso em: 16 nov. 2018.

DIEGO, Marcelo da Rocha Lima. Ópera flutuante: teatro lírico, literatura e sociedade no Rio de Janeiro do Segundo Reinado. 2009. 285 f. Orientador: Pedro Meira Monteiro. Tese (Doutorado em Espanhol e Português) Department of Spanish and Portuguese, Princeton University, Princeton, 2018.

FARIA, João Roberto. Machado de Assis - tradutor de teatro. Machado de Assis em Linha - Revista Eletrônica de Estudos Machadianos, São Paulo, v. 2, n. 6, p. 48-60, dez. 2010. Disponível em: <http://machadodeassis.net/download/ numero06/num06artigo04.pdf >. Acesso em: 16 nov. 2018.

. O teatro realista no Brasil. São Paulo: Perspectiva, 1993.

GAZETA DE NOTÍCIAS. Rio de Janeiro, 12 set. 1876, p. 1.

HEITOR, Luiz. 150 anos de música no Brasil. Rio de Janeiro: José Olympio, 1956.

KIEFER, Bruno. História da música brasileira. Porto Alegre: Movimento, 1997.

MASSA, Jean-Michel. A juventude de Machado de Assis. Rio de Janeiro: Civilização Brasileira, 1971.

MONTEIRO, Pedro Meira. Oui, mais il faut parier. Fidelidade e dúvida no Memorial de Aires. Estudos Avançados, São Paulo, v. 22, n. 64, p. 291-324, 2008. Disponível em: <http://www.scielo.br/scielo.php?script=sci_arttext\&pid=S0 103-40142008000300018>. Acesso em: 16 nov. 2018.

NAPOLEÃO, Arthur. 07 de novembro de 1876. Gazeta de Notícias, Rio de Janeiro, 07 nov. 1876, p. 1.

O CANCIONEIRO DA BIBLIOTECA NACIONAL. In: Biblioteca Mundial Digital. Disponível em: <https://www.wdl.org/pt/item/13529/>. Acesso em: 16 nov. 2018.

PAES, José Paulo. Um aprendiz de morto. In: São Paulo: Cia. das Letras, 2008. p. 17-44.

PASSOS, Gilberto Pinheiro. As sugestões do Conselheiro. São Paulo: Ática, 1996.

SAMOYAULT, Tiphaine. A intertextualidade. São Paulo: Hucitec, 2008.

SAMPAIO, Luiz Paulo. O papel do piano para a vida musical e cultural do Rio de Janeiro desde o final do século XIX. Revista eletrônica de musicologia, Curitiba, v. XIII, jan. 2010. Disponível em: <http://www.rem.ufpr.br/_REM/ REMv13/07/03_sampaio/piano_rio_secXIX.htm>. Acesso em: 16 nov. 2018.

SARAIVA, Juracy Assmann. O circuito das memórias: narrativas autobiográficas romanescas de Machado de Assis. São Paulo: Edusp; Nankin, 2009. 
Machado de Assis em Linha — Universidade de São Paulo

http://machadodeassis.fflch.usp.br

VIEIRA, Yara Frateschi. Os Lais de Bretanha: voltando à questão da autoria. In: MONGELLI, Lênia Márcia (Org.). De cavaleiros e cavalarias: por terras de Europa e Américas. São Paulo: Humanitas, 2012. p. 655-668. Disponível em: $<$ http://editora.fflch.usp.br/sites/editora.fflch.usp.br/files/655-668.pdf>. Acesso em: 16 nov. 2018.

JURACY ASSMANN SARAIVA é pós-doutora em Teoria Literária pela Universidade Estadual de Campinas. Professora e pesquisadora da Universidade Feevale, Coordenadora do PPG em Processos e Manifestações e bolsista de produtividade do CNPq. E-mail: jias@sinos.net

Recebido: 16.11 .2018

Aprovado: 15.01.2019 